\title{
Expert recommendations to personalization of medical approaches in treatment of multiple sclerosis: an overview of family planning and pregnancy
}

Nadja Borisow ${ }^{1 *}$, Andrea Döring ${ }^{1}$, Caspar F Pfueller ${ }^{1}$, Friedemann Paull $^{1}$, Jan Dörr ${ }^{1}$ and Kerstin Hellwig ${ }^{2}$

\begin{abstract}
Multiple sclerosis is the most common chronic autoimmune disease of the central nervous system which preferentially affects females at childbearing age. For this reason, patients and treating physicians were frequently confronted with questions concerning family planning, pregnancy and birth. Preventive and personalized treatment approaches are considered, because topics as heredity, risk of congenital malformations, influence of pregnancy on MS and aspects of drug therapy during the period of conception, pregnancy, puerperium and lactation have to be discussed. Here, we provide an overview about the current state of knowledge regarding these issues.
\end{abstract}

\section{Review}

\section{Introduction}

Multiple sclerosis (MS) is a chronic autoimmune disease of the central nervous system which, at the beginning, typically arises with relapsing episodes of neurological deficiencies. Subsequently, symptoms may persist, and in approximately $65 \%$ of the patients, a conversion into a secondary progressive (SP) course with a continuous deterioration of disability occurs. Patients $(15-20 \%$ of the patients suffer from a primary progressive (PP) MS with a steady worsening of symptoms from onset [1]).

Until now, pathomechanisms of MS are not sufficiently understood. Inflammatory demyelinating as well as neuroaxonal degenerative processes are involved in pathogenesis and result in cerebral and spinal tissue damage [1].

Treatment of acute exacerbation includes usually the application of intravenous methylprednisolone for 3 to 5 days [2,3]. To reduce frequency and severity of relapses as well as the progression of disease in general, an immunomodulatory therapy with interferon beta $($ IFN- $\beta)$ or glatiramer acetate $(\mathrm{GA})$ is necessary $[4,5]$. In

\footnotetext{
* Correspondence: nadja.borisow@charite.de

${ }^{1}$ NeuroCure Clinical Research Center and Clinical and Experimental Research Center for Multiple Sclerosis, Charité - Universitätsmedizin Berlin, Charitéplatz 1, Berlin 10117, Germany

Full list of author information is available at the end of the article
}

patients with high disease activity or insufficient effect of IFN- $\beta$ or GA, the monoclonal antibody natalizumab or the sphingosine receptor modulator, fingolimod, is available $[6,7]$. Another agent, which is approved for secondline-therapy, is mitoxantrone [8]. Of particular importance to reduce relapses and disease progression is an early initiation as well as a long-lasting and continuous administration of these therapies $[9,10]$.

In Europe, MS prevalence rates range between 10 and 187 per 100,000 with a higher rate in northern countries [11]. In Germany, approximately 120,000 people suffer from MS [12]. Patients typically experience first symptoms between the 3rd and 5th decade of life, and thus, MS mainly affects patients in childbearing age. It shows a female predominance of 2 to 3:1 [11-13]. Consequently, a high need for counseling exists on topics as family planning, pregnancy and child birth. Seeing that even healthy couples have many concerns related to pregnancy, such concerns particularly apply to patients with chronic and progressive diseases such as MS.

As especially the field of family planning, pregnancy and child birth benefits from a shift from delayed interventional to preventive and personalized medicine, in this article, an update about the current state of knowledge regarding the process of decision making, heredity and fertility, as well as course and outcome of 
pregnancy, in MS is given. Furthermore, we want to discuss the influence of pregnancy and childbirth on the disease, aspects of breastfeeding and concomitant medication, and finally encourage MS patients not generally to abstain from child birth due to their disease.

\section{Influence of MS on family planning and personalized approach in decision making}

In patients with MS, a lot of different aspects and concerns influence the decision whether to bear a child or not [14]. In the past, especially during the first half of 20th century, female patients were often discouraged from becoming mother as pregnancy was considered to be a risk in MS [15]. Today, first and foremost, there is the fear about the future state of health and the associated ability of taking care for the baby. The unpredictable course of the disease and the known increase of relapses postpartum [16] lead to further uncertainty regarding getting pregnant. Disabilities, e.g., pareses or impaired coordination may result in a higher risk of injury for the infant. Further anxiety exists regarding genetic predisposition and passing the disease on to their offspring. Moreover, the necessity to pause virtually all established disease-modifying therapies during the period of conception, pregnancy and breastfeeding raises the possibility of disease progression. Frequently, patients feel pressured by family members or health professionals either to abstain from pregnancy due to various problems MS is related with or to bear children as soon as possible in an early stage of disease. The fear of asking others for help and finally financial restrictions are other aspects patients with MS are confronted with while planning a family. In a widely larger extent than in healthy women in patients with MS, other persons besides the partner are involved in the process of decision making regarding getting pregnant [17]. The patients try to get into conversation especially with other family members, foremost their mothers, as they are aware they could rely on them in case of a relapse. Depending on the relationship and the sense of togetherness within the family, these talks may be encouraging as well as dissuasive. Also, treating physicians were frequently consulted to achieve an additional advice from the medical point of view.

Several studies were published regarding the correlation between MS and family planning, especially child birth, to some extent with contradictory results. A French study revealed a relationship between age at onset of the MS and the number of children who are finally born [18]. A clear association between an early disease onset $(<25$ years) and a lower number of children could be shown, even though patients with an onset $>25$ years get less children than the general French population. Interestingly, there is no difference between men and women [18]. A Swedish study shows that, even at onset of the disease, the proportion of childless women is higher in female MS patients compared to healthy women of same age [19]. The reasons are not clear; maybe a reduced fertility even before onset of the disease has to be discussed.

\section{MS inheritance risk as factor influencing individual decision making in family planning}

From the perspective of preventive medicine, knowledge about inheritance risk is essential for making informed decision about planning or continuing a pregnancy. Broad consensus exists that environmental as well as genetic factors are involved in the etiology of MS. The lifetime risk for MS in the general population of northern Europe is $0.2 \%$ to $0.5 \%$ with higher rates in northern countries. As epidemiologic studies show, risk of MS increases with raising degree of kinship to a MS patient. Highest risks are described in monozygotic twins, followed by siblings, parents and children of MS patients [20-25]. Second and third degree relatives have a lower risk, although it is still higher than in general population. Among stepsiblings and adopted relatives, no elevated MS risk was found [26,27]. Table 1 gives an overview about studies examining risk of MS in children of male and female MS patients. If not mentioned by the authors, relative risks were calculated by using ageadjusted risks and lifetime risk in general population.

To sum up, children of MS patients are at 6- to 12fold risk of developing MS with age-adjusted risks ranging between $1.5 \%$ and $7 \%$. One study even describes a 50 -fold risk in daughters of MS patients [24], but all in all, the likelihood of not getting the disease in children of MS patients is approximately $97 \%$.

\section{Oral contraception - a measure of prevention in MS?}

As the intake of oral contraception might play a preventive role in MS, a couple of studies examined the influence of oral contraception on risk, onset and course of MS. In summary, there is no positive proof of an effect of oral contraceptives on the lifetime risk for development of MS [28-30]. In patients with PP MS, the use of oral contraception showed both a higher risk to reach an Expanded Disability Status Scale (EDSS) of 6 and a shorter duration between onset of MS and EDSS 6 [31]. In women with relapsing onset of the disease, no influence of oral contraception on disease progression was found. In contrast to that, another study suggests a protective effect of contraceptives as it shows a correlation between use of oral contraception and a higher age at onset, even though in this study, no differentiation between relapsing and progressive MS was conducted [32]. Another survey as well postulated a possible delay of MS onset in patients using oral contraceptives [33]. Finally, 
Table 1 Overview of studies on MS risk in children of MS patients

\begin{tabular}{|c|c|c|c|c|c|c|c|c|c|c|c|c|}
\hline \multirow{3}{*}{$\begin{array}{l}\text { Author } \\
\\
\text { Nielsen et al. } \\
{[20]}\end{array}$} & \multirow{3}{*}{$\begin{array}{l}\text { Year } \\
2005\end{array}$} & \multirow{3}{*}{$\begin{array}{l}\text { Country } \\
\text { Denmark }\end{array}$} & \multirow{3}{*}{$\begin{array}{l}\begin{array}{l}\text { Number } \\
\text { of } \\
\text { patients }\end{array} \\
8205\end{array}$} & \multirow{3}{*}{$\begin{array}{l}\begin{array}{l}\text { Estimated lifetime } \\
\text { risk in general } \\
\text { population (\%) }\end{array} \\
\text { Men, } 0.3 ; \\
\text { women, } 0.5\end{array}$} & \multicolumn{4}{|c|}{ Male MS patients } & \multicolumn{4}{|c|}{ Female MS patients } \\
\hline & & & & & \multicolumn{2}{|c|}{$\begin{array}{l}\text { Age-adjusted } \\
\text { risk for children }\end{array}$} & \multicolumn{2}{|c|}{$\begin{array}{l}\text { Relative risk } \\
\text { for children }\end{array}$} & \multicolumn{2}{|c|}{$\begin{array}{l}\text { Age-adjusted } \\
\text { risk for children }\end{array}$} & \multicolumn{2}{|c|}{$\begin{array}{l}\text { Relative risk } \\
\text { for children }\end{array}$} \\
\hline & & & & & - & & $\begin{array}{l}\text { Daughter } \\
\text { Son } \\
\text { Total }\end{array}$ & $\begin{array}{l}7.5 \\
7.5 \\
7.5\end{array}$ & - & & $\begin{array}{l}\text { Daughter } \\
\text { Son } \\
\text { Total }\end{array}$ & $\begin{array}{l}4.5 \\
9.5 \\
6.3\end{array}$ \\
\hline $\begin{array}{l}\text { Prokopenko } \\
\text { et al. [23] }\end{array}$ & 2003 & Italy (Sardinia) & 313 & 0.157 & - & & - & & Total & 3.19 & Total & 20.3 \\
\hline Carton et al. [22] & 1997 & Belgium & 674 & 0.175 & Total & 1.51 & Total & 8.6 & Total & 1.87 & Total & 10.7 \\
\hline $\begin{array}{l}\text { Robertson } \\
\text { et al. [21] }\end{array}$ & 1996 & UK & 674 & $\begin{array}{l}0.3 \text { (men, 0.13; } \\
\text { women, 0.66) }\end{array}$ & $\begin{array}{l}\text { Daughter } \\
\text { Son } \\
\text { Total }\end{array}$ & $\begin{array}{l}7.12 \\
2.54 \\
4.91\end{array}$ & $\begin{array}{l}\text { Daughter } \\
\text { Son } \\
\text { Total }\end{array}$ & $\begin{array}{l}10.8 \\
19.5 \\
16.4\end{array}$ & $\begin{array}{l}\text { Daughter } \\
\text { Son } \\
\text { Total }\end{array}$ & $\begin{array}{l}1.74 \\
0.0 \\
0.81\end{array}$ & $\begin{array}{l}\text { Daughter } \\
\text { Son } \\
\text { Total }\end{array}$ & $\begin{array}{l}2.6 \\
0.0 \\
2.7\end{array}$ \\
\hline $\begin{array}{l}\text { Sadovnick } \\
\text { and Baird [24] }\end{array}$ & 1988 & Canada & 815 & 0.1 & $\begin{array}{l}\text { Daughter } \\
\text { Son } \\
\text { Total }\end{array}$ & $\begin{array}{l}5.13 \\
0.0 \\
2.47\end{array}$ & $\begin{array}{l}\text { Daughter } \\
\text { Son } \\
\text { Total }\end{array}$ & $\begin{array}{l}51.3 \\
0.0 \\
24.7\end{array}$ & $\begin{array}{l}\text { Daughter } \\
\text { Son } \\
\text { Total }\end{array}$ & $\begin{array}{l}4.96 \\
0.0 \\
2.58\end{array}$ & $\begin{array}{l}\text { Daughter } \\
\text { Son } \\
\text { Total }\end{array}$ & $\begin{array}{l}49.6 \\
0.0 \\
25.8\end{array}$ \\
\hline
\end{tabular}

to further evaluate the impact of oral contraception on MS, it seems to be important to differentiate between inflammatory and degenerative processes in the disease course.

\section{Fertility in MS patients}

To explain the higher proportion of childlessness among MS patients, various factors have to be discussed. As mentioned above [19], among others, a reduction of fertility even in the preclinical phase of disease has to be considered. Fertility may be influenced by numerous parameters including sexual dysfunctions and hormonal alternations.

One study in 73 German female MS patients revealed an average period of 4 months to get pregnant and concluded no reduction in fertility in women with MS [34]. However, only females who were already mothers were included in this study which implies that women with limited fertility, leading to childlessness, were not taken into account at all. Thus, this study potentially underestimates the prevalence of reduced fertility in female MS patients. In fact, another survey found a significantly higher need for artificial insemination in female patients with MS compared to the general population obtained from Finnish Medical Birth Register [35].

Even in MS patients with mild neurologic deficits, up to $73 \%$ complain about sexual dysfunctions $[36,37]$. In female patients, reduced libido, decreased vaginal sensation and lubrication as well as difficulties in reaching an orgasm were described [38]. Male patients complain about erective dysfunction, impaired ejaculation, and just as female patients, about reduction of libido [39]. Despite same marital status, a significantly lower frequency of sexual intercourse in patients with MS compared to both healthy controls and patients with rheumatic diseases, especially with rheumatoid arthritis, can be detected [37]. In addition to sexual dysfunctions caused by MS, other disease-related physical impairments may interfere with sexual activity. Above all, fatigue is a frequently mentioned symptom; furthermore, muscle weakness, constraints of coordination, pain, spasticity and impaired sensation may have negative effects on sexuality. In addition, medication used to treat attendant symptoms as depression, anxiety, or urinary urgency may account for sexual dysfunctions. That is why a personalized approach to concomitant medication is required, particularly in MS patients at childbearing age.

Several hormonal alterations which may interfere with fertility have been described in patients with MS. Significantly higher levels of FSH, LH, prolactin and testosterone were detectable in female patients [40]. In men, lower levels of testosterone, $\mathrm{LH}$ and $\mathrm{FSH}$, as well as pathologic GnRH and hCG tests, were observed. Above all, pathologic spermiograms with a reduced number and motility of semen were described [41].

Besides these aspects, psychological factors may not be underestimated. Shame because of physical disabilities, bladder or bowel dysfunctions, inserted catheters, or the fear of disapproval by the partner may lead to avoidance of sexual contacts. Whether and to what degree these factors in detail lead to a higher rate of undesired childlessness in MS-patients is not clear. To our clinical experience, fertility is not reduced in a significant way in MS patients; besides this, most women become pregnant in the earlier phase of the disease without profound disability.

\section{Influence of motherhood on MS}

Studies analyzing the influence of pregnancy and child birth on incidence, onset, course, or severity of MS under the aspect of a possibly preventive effect have to be interpreted with caution as cause and effect are difficult to differentiate. A Danish study investigated the relationship between the number of born children and the 
likelihood of developing MS [42]. The risk of MS was inversely associated with the number of born children and with the age at birth of the first child. Furthermore, the MS risk was reported to increase with time since birth of the most recent child. Moreover, the number of children born before diagnosis of MS is associated with a higher age at onset of the disease [32]. In addition, the pregnancy with or birth of at least two children leads to a lower likelihood to reach an EDSS score of 6, respectively to the extension of the period until EDSS 6 is achieved, at least in patients with relapsing-remitting (RR) MS [31]. If the first child is born after onset of MS, the risk of conversion from RR MS to SP MS is lower compared to women whose children were born before onset of the disease [19]. Furthermore, pregnancy after onset of MS is associated with a longer duration until wheelchair dependence develops compared to patients who were never pregnant or born children only before onset of the disease [43]. To sum up, motherhood does not seem to have negative effects on risk or course of MS, although the interpretations of all these studies need to factor a possible bias as women with severe course of the disease may tend to prevent pregnancies, and rather patients with benign forms or late onset of the disease decide to become pregnant.

\section{Influence of pregnancy on MS course}

The level of knowledge about the effect of pregnancy on MS and vice versa is low in female patients [44], although numerous studies investigated the influence of pregnancy on MS. A prospective study examining the course of pregnancy in about 250 patients, the PRIMS study, revealed a reduction of the relapse rate during pregnancy, especially during the third trimester [16]. Over a period of 3 months after delivery, relapse rate increased to a level higher than before pregnancy followed by a decrease to pre-pregnancy rate during the next 6 to 9 months. These results confirmed the findings of previous partly retrospective, partly quite small studies [45-47] and were verified by following surveys $[48,49]$. Relapses in the year before and during pregnancy are supposed to be a risk factor as they lead to a 1.7- to 1.8-fold increase of postpartum relapses [50], although these results could not be confirmed by another survey [51].

Immunologic changes during pregnancy aiming at protecting the fetus from maternal immune defense are supposed to lead to the observed reduction of disease activity during proceeding pregnancy. An increase of $\mathrm{CD}^{+} / \mathrm{CD}^{+}$ratio and a decrease of $\mathrm{CD} 16^{+}$natural killer (NK) cells during pregnancy, followed by a decline in $\mathrm{CD}^{+} / \mathrm{CD}^{+}$ratio and a rise in $\mathrm{CD} 16^{+} \mathrm{NK}$ cells after delivery may represent a correlate of maternal immune suppression which may explain some of the detected changes in disease activity during and directly following pregnancy [52].

\section{Assisted reproduction technique in MS patients}

As approximately $10 \%$ to $15 \%$ of all couples in general population remain undesirably childless, artificial fertilization may also be necessary in patients with MS. Until now, three studies investigated the effect of assisted reproduction technique (ART) on the course of the disease. Laplaud et al. found an increased relapse rate in patients treated with LHRH agonists, but not in females after treatment with LHRH antagonists [53]. Two further surveys confirmed the observed elevation in relapse rate during ART, although in these studies, the increased relapse rate was not dependent on the type of hormonal treatment $[54,55]$. Generally, we do not recommend to refrain from ART but inform about the increased risk and counsel to stay on MS treatment while undergoing ART.

\section{Multidisciplinary approaches on course and outcome of pregnancy in MS patients}

Additional causes of concern in expectant mothers with MS are possible complications during pregnancy or delivery. A study comparing 432 births in 321 MS patients with healthy controls showed no differences in birth weight, mean gestational age, labor duration or 5-mine APGAR score [56]. Some surveys revealed a significant lower birth weight in newborns of MS patients, although the difference was low, ranging between 108 and $123 \mathrm{~g}$ [57,58]. A meta-analysis evaluating the results of 22 studies published between 1983 and 2009 found no elevated risk of low birth weight by analyzing the proportion of newborns with a birth weight $<2500 \mathrm{~g}$. Furthermore, no increased rate of abortions, prematurity, malformations or neonatal deaths in children of female MS patients was detected [59]. One study in nearly 200 pregnant women with MS provided evidence for a significantly higher rate of maternal anemia which is, due to a chronic intrauterine hypoxia, supposed to be the reason for a higher rate of meconium aspiration in infants of MS patients [60]. Despite these complications, no differences in duration and way of delivery, APGAR score directly after birth or necessity of assisted ventilation were detectable. The frequency of other pregnancyrelated complications, such as gestational diabetes mellitus or preeclampsia, was comparable to healthy controls.

In some surveys, operative deliveries with use of forceps or vacuum extraction were more frequent in MS patients $[35,57,60]$, which is attributed to a higher risk of exhaustion and slow progression of delivery in these patients. The rate of deliveries by cesarean section among MS patients shows a wide range between 10\% and $40 \%$ [59]. In general, proportion of cesarean section 
in healthy women differs a lot between various countries, influenced by social, religious and cultural factors. Concern regarding present or potential MS-related symptoms during delivery, such as spasticity, neuromuscular perineal weakness or exhaustion, is a factor that may influence the decision of patients and physicians in favor of cesarean section. Delivery mode and use of epidural analgesia do not influence postpartum relapse rate [16]. Taken together, the fact of suffering from MS is no reason to choose cesarean section instead of vaginal delivery, but obstetrical rationale should be the basis for decision making. Multidisciplinary approaches are required to guarantee an optimized treatment.

It has to be taken into account that some cohorts, investigated for pregnancy outcomes, included, first and foremost, women with a low EDSS score $[35,56]$. Data on rate of pregnancy and delivery complications in women with higher disability are rare, most likely because they are difficult to recruit, as women with distinct deficits rather avoid pregnancies. Furthermore, a higher rate of obesity in women with MS, e.g., due to less activity caused by physical disability, is discussed to possibly elevate the risk of complications during pregnancy and delivery.

\section{Breastfeeding - a countermeasure against postpartum relapses?}

Several studies examined the influence of breastfeeding on the course of the disease, especially on the occurrence and frequency of postpartum relapses, with finally inconsistent results. Some studies postulated a protective effect of exclusive breastfeeding [61-63] with a significantly higher risk for postpartum relapses in women that abstain from nursing. One study described a correlation between a decrease in interferon gamma producing CD4 ${ }^{+}$cells and postpartum relapses, which may be prevented by exclusive breastfeeding due to lactational amenorrhea [64]. On the other hand, the PRIMS study and a number of further investigations found no relationship between breastfeeding and postpartum relapses $[16,65,66]$. The major difficulty in all these studies is to correctly interpret the causality, as many women stop breastfeeding due to a relapse and treatment with corticosteroids, which may be suggestive of a higher rate of relapses in women that do not nurse at all or only for a short period of time. Except the fact that there is no proof of negative effects of nursing on the course of MS, at the moment, a clear recommendation regarding breastfeeding as a measure for prevention of postpartum relapses cannot be made. The appreciation between early resumption or the beginning of immunomodulatory therapy after delivery on one hand and the beneficial effects of breast milk on the other hand raises a lot of uncertainties. As long as no advantage of breastfeeding on MS course is proven, treating physicians together with the patient have to weigh up the benefit and the risk for relapses by taking into consideration the frequency and severity of disease course before pregnancy to realize an individually tailored and optimized medical care.

\section{Personalized medication during pregnancy - a challenge in MS treatment}

The topic which certainly requires most counseling in patients with MS who wish to conceive is the field of concomitant medication. This contains disease-modifying therapy, immunosuppressive agents and steroids, as well as medication required to treat MS-related symptoms.

As no reliable data concerning safety during pregnancy exist, it is generally recommended to discontinue diseasemodifying therapy as IFN- $\beta$ or GA either at the beginning of unprotected sexual intercourse or at the latest after pregnancy becomes known. Although data regarding drug exposure in human gravidity mainly result from unplanned pregnancies and are usually restricted to the first weeks of pregnancy, they are of particular importance as they help to make personalized treatment decisions in pregnant MS patients.

One study showed a significantly increased rate of spontaneous abortion and a reduction of birth weight after exposure to IFN- $\beta$ [67]. Reduced birth weight could be confirmed in some surveys $[68,69]$, whereas others found no reduction in birth weight or increased rate of spontaneous abortion, still birth and congenital abnormalities [70-76]. A small survey, including ten patients who continued therapy with IFN- $\beta$ or GA during whole pregnancy and postpartum, revealed no increased rate of spontaneous abortion but lower birth weight and earlier delivery after GA exposure [69]. Table 2 provides an overview about the results of different studies on birth outcome after exposure to IFN- $\beta$ and/or GA. To sum up, IFN- $\beta$ and GA seem to be considerably safe during pregnancy, so an induced abortion after exposure is not mandatory. Regarding the safety of disease-modifying therapy in male MS patients, one only partly prospective study exists which did not show reduced birth weight or length in comparison to babies of healthy women [77].

Regarding the application of natalizumab during pregnancy, approximately 40 patients are reported in the literature, one case with accidental exposure until the third trimester [78-80]. No elevated risks for spontaneous abortion, reduction of birth weight or lengths especially congenital malformation were found; however; due to the sparse data it is not possible to rule out rare complications.

As animal studies in fingolimod showed increased rates of miscarriage and vascular malformations, its use 
Table 2 Overview of studies on birth outcome after exposure to IFN- $\beta$ or GA

\begin{tabular}{|c|c|c|c|}
\hline \multirow[t]{2}{*}{ Author } & \multicolumn{2}{|c|}{$\begin{array}{l}\text { Number of pregnancies with } \\
\text { exposure to immunomodulatory } \\
\text { therapy }\end{array}$} & \multirow[t]{2}{*}{ Results } \\
\hline & IFN- $\beta$ & GA & \\
\hline Boskovic et al., 2005 [67] & 23 & & $\begin{array}{l}\text { Increased rate of spontaneous abortion (39\%); decreased birth weight, } \\
\text { two major birth defects (Down syndrome, X-chromosome abnormality) }\end{array}$ \\
\hline Sandberg-Wollheim et al., 2005 [73] & 41 & & Normal spontaneous abortion rate, one birth defect (hydrocephalus) \\
\hline Patti et al., 2008 [72] & 14 & & $\begin{array}{l}\text { Normal spontaneous abortion rate and birth weight; shorter gestational } \\
\text { period ( } 37.8 \text { weeks), no malformations }\end{array}$ \\
\hline Hellwig et al., 2009 [71] & 17 & & Normal miscarriage rate $(2 / 17)$ and birth weight \\
\hline $\begin{array}{l}\text { Weber-Schoendorfer and Schaefer, } \\
2009 \text { [75] }\end{array}$ & 69 & 31 & $\begin{array}{l}\text { Normal spontaneous abortion rate and birth weight, no preterm delivery; } \\
\text { two major birth defects (club feet, AV canal) under GA }\end{array}$ \\
\hline Amato et al., 2010 [68] & 88 & & $\begin{array}{l}\text { Normal spontaneous abortion rate; lower birth weight and length; } \\
\text { no major birth defects }\end{array}$ \\
\hline Salminen et al., 2010 [76] & & 13 & $\begin{array}{l}\text { In 9/13 exposure during whole pregnancy, normal spontaneous abortion } \\
\text { rate and birth weight, no birth defects }\end{array}$ \\
\hline Fragoso et al., 2010 [74] & & 11 & $\begin{array}{l}\text { Exposure }>7 \text { months during pregnancy; normal spontaneous abortion } \\
\text { rate, birth weight and length }\end{array}$ \\
\hline Sandberg-Wollheim et al., 2011 [70] & 425 & & $\begin{array}{l}\text { Normal spontaneous abortion rate, three major birth defects (VACTERL } \\
\text { syndrome, tetralogy of Fallot, solitary kidney) }\end{array}$ \\
\hline Hellwig et al., 2011 [69] & 7 & 3 & $\begin{array}{l}\text { Exposure during whole pregnancy; lower birth weight and earlier delivery } \\
\text { (GA); one malformation in IFN (valvular stenosis of pulmonary artery), one } \\
\text { in GA (penile hypospadia) }\end{array}$ \\
\hline
\end{tabular}

during pregnancy is not recommended, although experience in human pregnancy is missing.

Glucocorticoids are not considered to be safe during the first 3 months of pregnancy, as an increased risk of oral clefts cannot be excluded [81]. Furthermore, higher rates of miscarriage and preterm births, as well as lower birth weight, have been described [82]. In cases of severe relapses glucocorticosteroids can be taken into account individually. Beyond the first trimester, the use of glucocorticoids does not seem to be harmful to the baby [83].

In MS, chemotherapeutic agents are used as second- or third-line therapy in highly active relapsing-remitting MS or in progressive courses, but due to a high rate of side effects, their use is limited. They are, in general, not recommended during pregnancy, partly because of known teratogenicity, partly due to missing data regarding possible effects on and risks for embryo- or fetogenesis in human. Methotrexate, as well as other chemotherapeutics, is contraindicated during pregnancy, as it leads to spontaneous abortions and congenital malformations [84]. According to manufacturers' information, cyclophosphamide is mutagenic; in the case of an exposure during first trimester of pregnancy, counseling regarding induced abortion should be provided. The FDA classifies cyclophosphamide within category D, which means that fetal risks are known, but in individual cases, the potential benefit may outbalance the risk. Two surveys report the neonatal outcome after mitoxantrone exposure during pregnancy in MS patients; one of them describes growth restriction without evidence of congenital malformation [85], and in another case, a child with
Pierre Robin sequence was born [86]. Mitoxantrone is also classified within category D by FDA. In azathioprine, until now, no teratogenic effect was reported in humans; nevertheless, it should only be used after strict risk-benefit analysis because, in some newborns, leuko- and/or thrombopenia were described.

Intravenous immunoglobulin (IVIG) is supposed to be safe during pregnancy as no negative effects on gravidity or fetal development have been reported. A retrospective study found a significant reduction of relapse rate by IVIG administration during pregnancy and postpartum without any serious adverse effects [87]. However, IVIGs are not approved for MS treatment in general, and not much information about the efficacy for acute relapses is available.

Table 3 summarizes FDA pregnancy classification of different immunomodulatory and immunosuppressive medication used in MS therapy.

Medication to treat MS-associated symptoms, e.g., oxybutynin in neurogenic bladder dysfunction, spasmolytics as baclofen and tizanidine, or antidepressants such as amitriptyline, citalopram or mirtazapine should only be used after careful consideration between risks for the unborn and gain for the mother. A detailed discussion on supportive treatment options in the context of pregnancy is, however, beyond the scope of this article.

\section{Prevention of postpartum relapses}

Especially the first months after delivery pose a challenge for the newly minted parents and are particularly 
important for the relationship between mother and child. Unfortunately, just in the first 3 months after child birth, the relapse rate in MS patients markedly increases. Thus, finding an effective prevention for postpartum relapses is a matter of particular importance. Based on the hypothesis of a progestin-mediated immunological shift from Th1 to Th2 response, which is considered an important cause of reduced relapse rate during pregnancy, the POPART'MUS study examines the potential of progestin and estradiol in preventing postpartum relapses [88]. It is a prospective, placebo-controlled and double-blinded study that aims to recruit 300 patients and is still ongoing.

Intravenous corticosteroids are supposed to reduce postpartum relapse rate [89]; however; until now; prospective randomized double-blinded studies are missing. A postpartum therapy with intravenous immunoglobulin as well reduced the number of relapses [62,90]. Moreover, in contrast to IFN- $\beta$ or GA, breastfeeding is possible while receiving IVIG. If treatment with IVIG already started during pregnancy, an even additional reduction of relapse rate may be achieved [87]. Finally, further large scale studies, preferably placebo controlled, are required to confirm the positive effects of glucocorticoids and IVIG in the prevention of postpartum relapses.

\section{Being parent with MS}

Many expectant mothers with MS ask themselves if they will be able to deal with everyday life after delivery and if despite their disease they will be able to be a good mother. An important role in the daily routine of newly minted mothers with MS plays the economizing of their physical resources. As exhaustion affects even healthy mothers during the first months after delivery, it impacts mothers with MS in a particular degree. Interviews with mothers with MS show that they pass on to a forwardlooking planning of daily household activities which markedly alleviates to conserve their energies [17]. Female patients with children seem to have a higher quality of life compared to childless MS patients, at least concerning the domain of social function [91]. On the other hand, in mothers with MS, the concern for children correlates with depressive symptoms, but social support may at least partly alleviate them [92]. Finally, being a good mother and taking care for a baby is also possible with a disease like MS, although the social support is even more important than for healthy mothers.

\section{Conclusions}

A lot of questions arise if patients with MS get pregnant or plan to conceive. It is important not to discourage these women but to comprehensively inform about possible risks and specific features of pregnancy in MS. These include a slightly elevated risk for heredity, the possibility of disease-related sexual dysfunctions and an increase of relapse rate during puerperium. On the other hand, specific complications during pregnancy or congenital abnormality are not to be feared for. Patients have to be aware of limited knowledge about the effect of various MS medication on pregnancy as well as that, until now, an unambiguous recommendation of breastfeeding is not possible. Thus, a weighting between risk and benefit is frequently necessary, which should always be done after detailed counseling and together with an experienced physician. Prevention of postpartum relapses poses a challenge for the future to encourage even more patients to fulfill their desire to start a family.

Table 3 FDA pregnancy categories

\begin{tabular}{|c|c|c|}
\hline FDA pregnancy category & Description & Drug \\
\hline B & $\begin{array}{l}\text { Animal studies have revealed no evidence of harm to the fetus; however, there are no } \\
\text { adequate and well-controlled studies in pregnant women. } \\
\text { Or } \\
\text { Animal studies have shown an adverse effect, but adequate and well-controlled studies } \\
\text { in pregnant women have failed to demonstrate a risk to the fetus in any trimester. }\end{array}$ & Glatiramer acetate \\
\hline $\mathrm{C}$ & $\begin{array}{l}\text { Animal studies have shown an adverse effect and there are no adequate and } \\
\text { well-controlled studies in pregnant women. } \\
\text { Or } \\
\text { No animal studies have been conducted, and there are no adequate and well-controlled } \\
\text { studies in pregnant women. }\end{array}$ & $\begin{array}{l}\text { IFN- } \beta \text {, natalizumab, } \\
\text { fingolimod, dexamethasone, } \\
\text { prednisolone, } \\
\text { IVIG and cyclosporin A }\end{array}$ \\
\hline $\bar{D}$ & $\begin{array}{l}\text { Adequate well-controlled or observational studies in pregnant women have } \\
\text { demonstrated a risk to the fetus. However, the benefits of therapy may outweigh the } \\
\text { potential risk. For example, the drug may be acceptable if needed in a life-threatening } \\
\text { situation or serious disease for which safer drugs cannot be used or are ineffective. }\end{array}$ & $\begin{array}{l}\text { Cyclophosphamide, } \\
\text { azathioprine } \\
\text { and mitoxantrone }\end{array}$ \\
\hline $\mathrm{x}$ & $\begin{array}{l}\text { Adequate well-controlled or observational studies in animals or pregnant women have } \\
\text { demonstrated positive evidence of fetal abnormalities or risks. The use of the product is } \\
\text { contraindicated in women who are or may become pregnant. }\end{array}$ & Methotrexate \\
\hline
\end{tabular}




\section{Competing interests}

The authors declare that they have no competing interests.

\section{Acknowledgment}

This work was supported by the DFG (Exc 257).

\section{Author details}

${ }^{1}$ NeuroCure Clinical Research Center and Clinical and Experimental Research Center for Multiple Sclerosis, Charité - Universitätsmedizin Berlin, Charitéplatz 1, Berlin 10117, Germany. ²Department of Neurology, St. Josef Hospital, Ruhr University Bochum, Bochum 44801, Germany.

\section{Authors' contributions}

NB performed literature search, identified relevant studies and wrote the final review. JD and $\mathrm{KH}$ acted as review authors and provided content expertise. FP, CP and AD provided further content expertise and read and commented on drafts. All authors read and approved the final manuscript.

Received: 17 May 2012 Accepted: 22 June 2012

Published: 22 June 2012

\section{References}

1. Compston A, Coles A: Multiple sclerosis. Lancet 2008, 372:1502-1517.

2. Milligan NM, Newcombe R, Compston DA: A double-blind controlled trial of high dose methylprednisolone in patients with multiple sclerosis: 1. Clinical effects. J Neurol Neurosurg Psychiatry 1987, 50:511-516.

3. Thrower BW: Relapse management in multiple sclerosis. Neurologist 2009, 15:1-5.

4. Buck D, Hemmer B: Treatment of multiple sclerosis: current concepts and future perspectives. J Neurol 2011, 258:1747-1762

5. Mendes A, Sá MJ: Classical immunomodulatory therapy in multiple sclerosis: how it acts, how it works. Arq Neuropsiquiatr 2011, 69:536-543.

6. Del Santo F, Maratea D, Fadda V, Trippoli S, Messori A: Treatments for relapsing-remitting multiple sclerosis: summarising current information by network meta-analysis. Eur J Clin Pharmacol 2012, 68:441-448.

7. Pucci E, Giuliani G, Solari A, Simi S, Minozzi S, Di Pietrantonj C, Galea l: Natalizumab for relapsing remitting multiple sclerosis. Cochrane Database Syst Rev 2011, doi:10.1002/14651858.CD007621.pub2.

8. Scott LJ, Figgitt DP: Mitoxantrone: a review of its use in multiple sclerosis. CNS Drugs 2004, 18:379-396.

9. Kappos L, Traboulsee A, Constantinescu C, Erälinna J-P, Forrestal F, Jongen P, Pollard J, Sandberg-Wollheim M, Sindic C, Stubinski B, Uitdehaag B, Li D: Long-term subcutaneous interferon beta-1a therapy in patients with relapsing-remitting MS. Neurology 2006, 67:944-953.

10. Ford C, Goodman AD, Johnson K, Kachuck N, Lindsey JW, Lisak R, Luzzio C, Myers L, Panitch H, Preiningerova J, Pruitt A, Rose J, Rus H, Wolinsky J: Continuous long-term immunomodulatory therapy in relapsing multiple sclerosis: results from the 15-year analysis of the US prospective open-label study of glatiramer acetate. Mult Scler 2010, 16:342-350.

11. Pugliatti M, Rosati G, Carton H, Riise T, Drulovic J, Vécsei L, Milanov I: The epidemiology of multiple sclerosis in Europe. Eur J Neurol 2006, 13: 700-722.

12. Hein T, Hopfenmüller W: Hochrechnung der zahl an multiple sklerose erkrankten patienten in Deutschland. Nervenarzt 2000, 71:288-294.

13. Koutsouraki E, Costa $V$, Baloyannis S: Epidemiology of multiple sclerosis in Europe: a review. Int Rev Psychiatry 2010, 22:2-13.

14. Prunty M, Sharpe L, Butow P, Fulcher G: The motherhood choice: themes arising in the decision-making process for women with multiple sclerosis. Mult Scler 2008, 14:701-704.

15. Schapira K, Poskanzer DC, Newell DJ, Miller H: Marriage, pregnancy and multiple sclerosis. Brain 1966, 89:419-428.

16. Confavreux C, Hutchinson M, Hours MM, Cortinovis-Tourniaire P, Moreau T: Rate of pregnancy-related relapse in multiple sclerosis. Pregnancy in multiple sclerosis group. N Engl J Med 1998, 339:285-291.

17. Payne D, McPherson KM: Becoming mothers. Multiple sclerosis and motherhood: a qualitative study. Disabil Rehabil 2010, 32:629-638.

18. Verdier-Taillefer $\mathrm{MH}$, Alperovitch $\mathrm{A}$ : The relationship of patients' sex to reproduction in multiple sclerosis. J Epidemiol Community Health 1990, 44:77.

19. Runmarker B, Andersen O: Pregnancy is associated with a lower risk of onset and a better prognosis in multiple sclerosis. Brain 1995, 118:253-261.
20. Nielsen NM, Westergaard T, Rostgaard K, Frisch M, Hjalgrim H, Wohlfahrt J, Koch-Henriksen N, Melbye M: Familial risk of multiple sclerosis: a nationwide cohort study. Am J Epidemiol 2005, 162:774-778.

21. Robertson NP, Fraser M, Deans J, Clayton D, Walker N, Compston DA: Age-adjusted recurrence risks for relatives of patients with multiple sclerosis. Brain 1996, 119:449-455.

22. Carton H, Vlietinck R, Debruyne J, De Keyser J, D'Hooghe MB, Loos R, Medaer R, Truyen L, Yee IM, Sadovnick AD: Risks of multiple sclerosis in relatives of patients in Flanders, Belgium. J Neurol Neurosurg Psychiatry 1997, 62:329-333.

23. Prokopenko I, Montomoli C, Ferrai R, Musu L, Piras ML, Ticca A, Murgia BS, Bernardinelli $L$ : Risk for relatives of patients with multiple sclerosis in central Sardinia, Italy. Neuroepidemiology 2003, 22:290-296.

24. Sadovnick AD, Baird PA: The familial nature of multiple sclerosis: age-corrected empiric recurrence risks for children and siblings of patients. Neurology 1988, 38:990-991.

25. Compston A: The genetic epidemiology of multiple sclerosis. Philos Trans R Soc Lond B Biol Sci 1999, 354:1623-1634

26. Dyment DA, Yee IM, Ebers GC, Sadovnick AD, Canadian Collaborative Study Group: Multiple sclerosis in stepsiblings: recurrence risk and ascertainment. J Neurol Neurosurg Psychiatry 2006, 77:258-259.

27. Ebers GC, Sadovnick AD, Risch NJ, Canadian Collaborative Study Group: A genetic basis for familial aggregation in multiple sclerosis. Nature 1995, 377:150-151.

28. Alonso A, Clark CJ: Oral contraceptives and the risk of multiple sclerosis: a review of the epidemiologic evidence. J Neurol Sci 2009, 286:73-75.

29. Hernán MA, Hohol MJ, Olek MJ, Spiegelman D, Ascherio A: Oral contraceptives and the incidence of multiple sclerosis. Neurology 2000 55:848-854.

30. Thorogood M, Hannaford PC: The influence of oral contraceptives on the risk of multiple sclerosis. Br J Obstet Gynaecol 1998, 105: 1296-1299.

31. D'hooghe MB, Haentjens P, Nagels G, D'Hooghe T, De Keyser J: Menarche, oral contraceptives, pregnancy and progression of disability in relapsing onset and progressive onset multiple sclerosis. J Neurol 2012, 259: 855-861.

32. Holmqvist $P$, Hammar M, Landtblom A-M, Brynhildsen J: Age at onset of multiple sclerosis is correlated to use of combined oral contraceptives and childbirth before diagnosis. Fertil Steril 2010, 94: 2835-2837.

33. Alonso A, Jick SS, Olek MJ, Ascherio A, Jick H, Hernán MA: Recent use of oral contraceptives and the risk of multiple sclerosis. Arch Neurol 2005 62:1362-1365.

34. Hellwig K, Brune N, Haghikia A, Müller T, Schimrigk S, Schwödiauer V, Gold $\mathrm{R}$ : Reproductive counseling, treatment and course of pregnancy in 73 German MS patients. Acta Neurol Scand 2008, 118:24-28.

35. Jalkanen A, Alanen A, Airas L, Finnish Multiple Sclerosis and Pregnancy Study Group: Pregnancy outcome in women with multiple sclerosis: results from a prospective nationwide study in Finland. Mult Scler 2010, 16:950-955.

36. Demirkiran M, Sarica Y, Uguz S, Yerdelen D, Aslan K: Multiple sclerosis patients with and without sexual dysfunction: are there any differences? Mult Scler 2006, 12:209-214.

37. Zorzon M, Zivadinov R, Bosco A, Bragadin LM, Moretti R, Bonfigli L, Morassi $P$, lona $L G$, Cazzato $G$ : Sexual dysfunction in multiple sclerosis: a case-control study. I. Frequency and comparison of groups. Mult Scler 1999, 5:418-427.

38. Sipski ML, Behnegar A: Neurogenic female sexual dysfunction: a review. Clin Auton Res 2001, 11:279-283.

39. Zorzon M, Zivadinov R, Monti Bragadin L, Moretti R, De Masi R, Nasuelli D, Cazzato G: Sexual dysfunction in multiple sclerosis: a 2-year follow-up study. J Neurol Sci 2001, 187:1-5.

40. Grinsted L, Heltberg A, Hagen C, Djursing H: Serum sex hormone and gonadotropin concentrations in premenopausal women with multiple sclerosis. J Intern Med 1989, 226:241-244.

41. Safarinejad MR: Evaluation of endocrine profile, hypothalamic-pituitarytestis axis and semen quality in multiple sclerosis. J Neuroendocrinol 2008, 20:1368-1375.

42. Nielsen NM, Jørgensen KT, Stenager $E$, Jensen A, Pedersen BV, Hjalgrim H, Kjær SK, Frisch M: Reproductive history and risk of multiple sclerosis. Epidemiology 2011, 22:546-552. 
43. Verdru P, Theys P, D'Hooghe MB, Carton H: Pregnancy and multiple sclerosis: the influence on long term disability. Clin Neurol Neurosurg 1994, 96:38-41.

44. Albrecht P, Fischer D, Moser A: Multiple sclerosis and pregnancy: what does the patient think? A questionnaire study. BMC Res Notes 2010, 3:91.

45. Birk K, Ford C, Smeltzer S, Ryan D, Miller R, Rudick RA: The clinical course of multiple sclerosis during pregnancy and the puerperium. Arch Neurol 1990, 47:738-742.

46. Nelson LM, Franklin GM, Jones MC: Risk of multiple sclerosis exacerbation during pregnancy and breast-feeding. JAMA 1988, 259:3441-3443.

47. Worthington J, Jones R, Crawford M, Forti A: Pregnancy and multiple sclerosis-a 3-year prospective study. J Neurol 1994, 241:228-233.

48. Finkelsztejn A, Fragoso YD, Ferreira ML, Lana-Peixoto MA, Alves-Leon SV, Gomes S, Damasceno BP, Mendes MF, Salgado PR, Correa EC, Comini-Frota ER, Diniz DS, Gama PD, Kaimen-Maciel DR, Morales RR, Arruda WO, Grzesiuk AK, Khouri JM, Lopes JS, Rocha CF, Domingues R, Gonçalves MV, Lorenti MA, Parolin MK, Siquineli F, Tosta ED, Brooks JB, Gallina AS, Melges LD, Ruocco $\mathrm{HH}$ : The Brazilian database on pregnancy in multiple sclerosis. Clin Neurol Neurosurg 2011, 113:277-280.

49. Salemi G, Callari G, Gammino M, Battaglieri F, Cammarata E, Cuccia G, D'Amelio M, Lupo I, Ragonese P, Savettieri G: The relapse rate of multiple sclerosis changes during pregnancy: a cohort study. Acta Neurol Scand 2004, 110:23-26.

50. Vukusic S, Hutchinson M, Hours M, Moreau T, Cortinovis-Tourniaire P, Adeleine P, Confavreux C, The Pregnancy In Multiple Sclerosis Group: Pregnancy and multiple sclerosis (the PRIMS study): clinical predictors of post-partum relapse. Brain 2004, 127:1353-1360.

51. Neuteboom RF, Janssens AC, Siepman TA, Hoppenbrouwers IA, Ketelslegers IA, Jafari N, Steegers EA, de Groot CJ, Hintzen RQ: Pregnancy in multiple sclerosis: clinical and self-report scales. J Neurol 2012, 259:311-317.

52. Saraste M, Väisänen S, Alanen A, Airas L, Finnish Multiple Sclerosis and Pregnancy Study Group: Clinical and immunologic evaluation of women with multiple sclerosis during and after pregnancy. Gend Med 2007, 4:45-55.

53. Laplaud DA, Leray E, Barrière $P$, Wiertlewski S, Moreau T: Increase in multiple sclerosis relapse rate following in vitro fertilization. Neurology 2006, 66:1280-1281.

54. Hellwig K, Beste C, Brune N, Haghikia A, Müller T, Schimrigk S, Gold R: Increased MS relapse rate during assisted reproduction technique. J Neurol 2008, 255:592-593.

55. Hellwig K, Schimrigk S, Beste C, Muller T, Gold R: Increase in relapse rate during assisted reproduction technique in patients with multiple sclerosis. Eur Neurol 2009, 61:65-68.

56. van der Kop ML, Pearce MS, Dahlgren L, Synnes A, Sadovnick D, Sayao AL, Tremlett H: Neonatal and delivery outcomes in women with multiple sclerosis. Ann Neurol 2011, 70:41-50.

57. Dahl J, Myhr KM, Daltveit AK, Hoff JM, Gilhus NE: Pregnancy, delivery, and birth outcome in women with multiple sclerosis. Neurology 2005, 65:1961-1963.

58. Dahl J, Myhr KM, Daltveit AK, Gilhus NE: Planned vaginal births in women with multiple sclerosis: delivery and birth outcome. Acta Neurol Scand Suppl 2006, (Suppl 183):51-54.

59. Finkelsztejn A, Brooks JB, Paschoal FM Jr, Fragoso YD: What can we really tell women with multiple sclerosis regarding pregnancy? A systematic review and meta-analysis of the literature. BJOG 2011, 118:790-797.

60. Mueller BA, Zhang J, Critchlow CW: Birth outcomes and need for hospitalization after delivery among women with multiple sclerosis. Am J Obstet Gynecol 2002, 186:446-452.

61. Langer-Gould A, Huang SM, Gupta R, Leimpeter AD, Greenwood E, Albers KB, Van Den Eeden SK, Nelson LM: Exclusive breastfeeding and the risk of postpartum relapses in women with multiple sclerosis. Arch Neurol 2009, 66:958-963.

62. Haas J, Hommes OR: A dose comparison study of IVIG in postpartum relapsing-remitting multiple sclerosis. Mult Scler 2007, 13:900-908.

63. Hellwig K, Haghikia A, Agne H, Beste C, Gold R: Protective effect of breastfeeding in postpartum relapse rate of mothers with multiple sclerosis. Arch Neurol 2009, 66:1580-1581.

64. Langer-Gould A, Gupta R, Huang S, Hagan A, Atkuri K, Leimpeter AD, Albers KB, Greenwood E, Van Den Eeden SK, Steinman L, Nelson LM: Interferongamma-producing $T$ cells, pregnancy, and postpartum relapses of multiple sclerosis. Arch Neurol 2010, 67:51-57.
65. Portaccio E, Ghezzi A, Hakiki B, Martinelli V, Moiola L, Patti F, La Mantia L, Mancardi GL, Solaro C, Tola MR, Pozzilli C, De Giglio L, Totaro R, Lugaresi A, De Luca G, Paolicelli D, Marrosu MG, Comi G, Trojano M, Amato MP, MS Study Group of the Italian Neurological Society: Breastfeeding is not related to postpartum relapses in multiple sclerosis. Neurology 2011, 77:145-150.

66. Airas L, Jalkanen A, Alanen A, Pirttilä T, Marttila RJ: Breast-feeding, postpartum and prepregnancy disease activity in multiple sclerosis. Neurology 2010, 75:474-476.

67. Boskovic R, Wide R, Wolpin J, Bauer DJ, Koren G: The reproductive effects of beta interferon therapy in pregnancy: a longitudinal cohort. Neurology 2005, 65:807-811.

68. Amato MP, Portaccio E, Ghezzi A, Hakiki B, Zipoli V, Martinelli V, Moiola L, Patti F, La Mantia L, Mancardi GL, Solaro C, Tola MR, Pozzilli C, De Giglio L, Totaro R, Lugaresi A, Di Tommaso V, Paolicelli D, Marrosu MG, Comi G, Pellegrini F, Trojano M, MS Study Group of the Italian Neurological Society: Pregnancy and fetal outcomes after interferon- $\beta$ exposure in multiple sclerosis. Neurology 2010, 75:1794-1802.

69. Hellwig K, Gold R: Glatiramer acetate and interferon-beta throughout gestation and postpartum in women with multiple sclerosis. $J$ Neurol 2011, 258:502-503.

70. Sandberg-Wollheim M, Alteri E, Moraga MS, Kornmann G: Pregnancy outcomes in multiple sclerosis following subcutaneous interferon beta-1a therapy. Mult Scler 2011, 17:423-430.

71. Hellwig K, Agne $H$, Gold R: Interferon beta, birth weight and pregnancy in multiple sclerosis. J Neurol 2009, 256:830-831

72. Patti F, Cavallaro T, Lo Fermo S, Nicoletti A, Cimino V, Vecchio R, Laisa P, Zarbo R, Zappia M: Is in utero early-exposure to interferon beta a risk factor for pregnancy outcomes in multiple sclerosis? J Neurol 2008, 255:1250-1253.

73. Sandberg-Wollheim M, Frank D, Goodwin TM, Giesser B, Lopez-Bresnahan M, Stam-Moraga M, Chang P, Francis GS: Pregnancy outcomes during treatment with interferon beta-1a in patients with multiple sclerosis. Neurology 2005, 65:802-806.

74. Fragoso YD, Finkelsztejn A, Kaimen-Maciel DR, Grzesiuk AK, Gallina AS, Lopes J, Morales NM, Alves-Leon SV, de Almeida SM: Long-term use of glatiramer acetate by 11 pregnant women with multiple sclerosis: a retrospective, multicentre case series. CNS Drugs 2010, 24:969-976.

75. Weber-Schoendorfer C, Schaefer C: Multiple sclerosis, immunomodulators, and pregnancy outcome: a prospective observational study. Mult Scler 2009, 15:1037-1042.

76. Salminen $H J$, Leggett $H$, Boggild M: Glatiramer acetate exposure in pregnancy: preliminary safety and birth outcomes. J Neurol 2010, 257:2020-2023.

77. Hellwig K, Haghikia A, Gold R: Parenthood and immunomodulation in patients with multiple sclerosis. J Neurol 2010, 257:580-583.

78. Hoevenaren IA, de Vries LC, Rijnders RJ, Lotgering FK: Delivery of healthy babies after natalizumab use for multiple sclerosis: a report of two cases. Acta Neurol Scand 2011, 123:430-433.

79. Hellwig K, Haghikia A, Gold R: Pregnancy and natalizumab: results of an observational study in 35 accidental pregnancies during natalizumab treatment. Mult Scler 2011, 17:958-963.

80. Bayas A, Penzien J, Hellwig K: Accidental natalizumab administration to the third trimester of pregnancy in an adolescent patient with multiple sclerosis. Acta Neurol Scand 2011, 124:290-292.

81. Park-Wyllie L, Mazzotta P, Pastuszak A, Moretti ME, Beique L, Hunnisett L, Friesen MH, Jacobson S, Kasapinovic S, Chang D, Diav-Citrin O, Chitayat D, Nulman I, Einarson TR, Koren G: Birth defects after maternal exposure to corticosteroids: prospective cohort study and meta-analysis of epidemiological studies. Teratology 2000, 62:385-392.

82. Gur C, Diav-Citrin O, Shechtman S, Arnon J, Ornoy A: Pregnancy outcome after first trimester exposure to corticosteroids: a prospective controlled study. Reprod Toxicol 2004, 18:93-101.

83. Ferrero S, Pretta S, Ragni N: Multiple sclerosis: management issues during pregnancy. Eur J Obstet Gynecol Reprod Biol 2004, 115:3-9.

84. Nurmohamed L, Moretti ME, Schechter T, Einarson A, Johnson D, Lavigne SV, Erebara A, Koren G, Finkelstein Y: Outcome following high-dose methotrexate in pregnancies misdiagnosed as ectopic. Am J Obstet Gynecol 2011, 205:533.e1-533.e3.

85. De Santis M, Straface G, Cavaliere AF, Rosati P, Batocchi AP, Caruso A: The first case of mitoxantrone exposure in early pregnancy. Neurotoxicology 2007, 28:696-697. 
86. Hellwig K, Schimrigk S, Chan A, Epplen J, Gold R: A newborn with Pierre Robin sequence after preconceptional mitoxantrone exposure of a female with multiple sclerosis. J Neurol Sci 2011, 307:164-165.

87. Achiron A, Kishner I, Dolev M, Stern Y, Dulitzky M, Schiff E, Achiron R: Effect of intravenous immunoglobulin treatment on pregnancy and postpartum-related relapses in multiple sclerosis. J Neurol 2004, 251:1133-1137.

88. Vukusic S, lonescu I, El-Etr M, Schumacher M, Baulieu EE, Cornu C, Confavreux C, Prevention of Post-Partum Relapses with Progestin and Estradiol in Multiple Sclerosis Study Group: The Prevention of Post-Partum Relapses with Progestin and Estradiol in Multiple Sclerosis (POPART'MUS) trial: rationale, objectives and state of advancement. J Neurol Sci 2009, 286:114-118.

89. de Seze J, Chapelotte M, Delalande S, Ferriby D, Stojkovic T, Vermersch P: Intravenous corticosteroids in the postpartum period for reduction of acute exacerbations in multiple sclerosis. Mult Scler 2004, 10:596-597.

90. Hellwig K, Beste C, Schimrigk S, Chan A: Immunomodulation and postpartum relapses in patients with multiple sclerosis. Ther Adv Neurol Disord 2009, 2:7-11.

91. Twork S, Wirtz M, Schipper S, Klewer J, Bergmann A, Kugler J: Chronical illness and maternity: life conditions, quality of life and coping in women with multiple sclerosis. Qual Life Res 2007, 16:1587-1594.

92. Harrison T, Stuifbergen A: Disability, social support, and concern for children: depression in mothers with multiple sclerosis. J Obstet Gynecol Neonatal Nurs 2002, 31:444-453.

doi:10.1186/1878-5085-3-9

Cite this article as: Borisow et al.: Expert recommendations to personalization of medical approaches in treatment of multiple sclerosis: an overview of family planning and pregnancy. The EPMA Journal 2012 3:9.

\section{Submit your next manuscript to BioMed Central and take full advantage of:}

- Convenient online submission

- Thorough peer review

- No space constraints or color figure charges

- Immediate publication on acceptance

- Inclusion in PubMed, CAS, Scopus and Google Scholar

- Research which is freely available for redistribution 